\title{
The Role of Blood Clot in Guided Bone Regeneration: Biological Considerations and Clinical Applications with Titanium Foil
}

\author{
Lucio Milillo $^{1}$, Fabrizio Cinone ${ }^{1}$, Federico Lo Presti ${ }^{2}$, Dorina Lauritano ${ }^{3}$ (D) and Massimo Petruzzi ${ }^{4, *(\mathbb{D})}$ \\ 1 Independent Researcher, 70126 Bari, Italy; lmilillo1@tin.it (L.M.); fabrizio.cinone@gmail.com (F.C.) \\ 2 B.L. Consulting S.A.S.-Schio-Vicenza, 36015 Schio, Italy; federicolopresti.contact@gmail.com \\ 3 Centre of Neuroscience of Milan, Department of Medicine and Surgery, University of Milano-Bicocca, \\ 20090 Monza, Italy; dorina.lauritano@unimib.it \\ 4 Department of Interdisciplinary Medicine, University of Bari “Aldo Moro”, 70126 Bari, Italy \\ * Correspondence: massimo.petruzzi@uniba.it
}

Citation: Milillo, L.; Cinone, F.; Lo Presti, F.; Lauritano, D.; Petruzzi, M. The Role of Blood Clot in Guided Bone Regeneration: Biological Considerations and Clinical Applications with Titanium Foil. Materials 2021, 14, 6642. https:// doi.org/10.3390/ma14216642

Academic Editor: Enrico Marchetti

Received: 21 September 2021

Accepted: 29 October 2021

Published: 4 November 2021

Publisher's Note: MDPI stays neutral with regard to jurisdictional claims in published maps and institutional affiliations.

Copyright: (c) 2021 by the authors. Licensee MDPI, Basel, Switzerland. This article is an open access article distributed under the terms and conditions of the Creative Commons Attribution (CC BY) license (https:// creativecommons.org/licenses/by/ $4.0 /)$.

\begin{abstract}
In Guided Bone Regeneration (GBR) materials and techniques are essential to achieve the expected results. Thanks to their properties, blood clots induce bone healing, maturation, differentiation and organization. The preferred material to protect the clot in Guided Bone Regeneration is the titanium foil, as it can be shaped according to the bone defect. Furthermore, its exposition in the oral cavity does not impair the procedure. We report on five clinical cases in order to explain the management of blood clots in combination with titanium foil barriers in different clinical settings. Besides being the best choice to protect the clot, the titanium foil represents an excellent barrier that is useful in GBR due to its biocompatibility, handling, and mechanical strength properties. The clot alone is the best natural scaffold to obtain the ideal bone quality and avoid the persistence of not-resorbed granules of filler materials in the newly regenerated bone. Even though clot contraction still needs to be improved, as it impacts the volume of the regenerated bone, future studies in GBR should be inspired by the clot and its fundamental properties.
\end{abstract}

Keywords: blood clot; titanium foil; bone augmentation; guided bone regeneration

\section{Introduction}

In the last five years, scientific articles about bone regeneration have demonstrated how surgical techniques and materials have constantly been developing. This aspect, associated with the evolution of dedicated biomaterials, offers multiple surgical approaches and opens new scenarios in patient selection and management [1-9].

Thanks to tissue engineering and regenerative medicine, the development of biomatrixes and scaffolds is increasing with the aim to induce tissue regeneration through the stimulation and the enhanced production of adhesion molecules and growth factors, creating an optimal extracellular environment.

The ideal regenerative materials should be applied in situ, avoiding pathological effects on the adjacent tissues and they should promote the enzymatic processes that lead to remodeling and substitution of the matrix as in physiological extracellular matrix (ECM) [10]. Indeed, tissue engineering aims at the development of grafts made by functional tissue capable of regenerating and substituting the physiological tissues, following a biomimetic approach.

In tissue engineering, the driving principle is to provide the right environment in order to steer cell differentiation with the desired phenotype at the right time and place [11]. To achieve these results, materials and methods are fundamental. This regenerative philosophy is discordant with the use of heterologous biomaterials that are not completely resorbed or that take a long time for integration into the host tissue [12-14]. 
Even if autologous bone transplantation is currently considered the gold standard in clinical practice, this approach presents variable reabsorption timing [15-19] and the procedure requires surgical techniques at high risk of complications [20]. Therefore, starting from Murray's intuition about the potential of clots as a natural scaffold in bone regeneration [21-23] and after the considerations based on his analysis, supporting evidence about the utilization of the blood clot in Guided Bone Regeneration (GBR) is actually required [24-26].

\section{The Blood Clot}

Murray demonstrated how, in a bone defect, it is sufficient to maintain the defect space to lead a spontaneous bone regeneration in a shorter time than a bone graft. Due to this fundamental observation, we analyze clot transformation starting from clot formation [21].

Clot formation is the first step in the wound healing process that immediately follows such traumatic events as dental extraction or bone fracture [27,28]. Kolar et al. [28] focused their studies on the immune response in the early stage of fracture healing while de Sousa Gomes et al. [27] described the clot arrangement and evolution in the post-extractive alveolar bone. For these reasons, clot should be considered a biomaterial containing all the requested information for physiological bone healing [27].

A histomorphometric study on primates underlined the events succeeding in the alveolar bone between 4 and 180 days following the dental extraction [29].

Even if different tissues have different growing times, clot organization, driven by peripheral information, is sufficient for bone differentiation as in natural GBR.

Melcher et al. [22], created a shield to isolate the bone defect and observed the proliferation of neo-generated bone grown over the edges of natural bone. Even in this case, it is possible to assert that bone regeneration started spontaneously from clot organization.

Due to the role of the blood clot in the early stages of the healing process and due to a clot being considered a concentrate of blood products, during these last years, many studies were focused on blood concentrates such as platelet-rich plasma (PRP), platelet-rich fibrin (PRF) and platelet-rich growth factor (PRGF) [30,31]. The behavior of blood derivates is different from the whole blood. There is no evidence sustaining that separation of blood concentrates from erythrocytes causes morphologic alterations in surgical sites [32-35]. In fact, erythrocytes play a pivotal role in clot formation, first of all in the proliferation of homogeneous fibrin networks. Following these observations, Wang et al. identified the clot as the best natural scaffold to fulfill bone defects, thus avoiding toxic reactions usually induced by a high concentration of growth factors [23]. In clinical practice, the use of blood products is the best option to achieve soft-tissue healing [27]. To corroborate this statement, it is interesting to observe the behavior of clots in the sinus lift. Lundgreen et al. [24] reported the new bone formation in sinus floor elevation following spontaneous healing, without any filler. Following this observation, implant techniques involving sinus lift, without the use of biomaterials, were developed [36-38].

Chipaila et al. [26] measured, for six months, the implant stability quotient (ISQ) after performing a sinus lift with simultaneous insertion of implants using equine collagen sponge as filling material. They noted that the ISQ was stabilized between the fourth and sixth months. Therefore, a biologically active bone was noted around the implants.

Lambert et al. [39] analyzing different methods for subantral regeneration in rabbits, compared protocols involving blood clot, autologous bone and bovine hydroxyapatite (BHA) as a filler.

All three fillers retained the space for bone formation and guaranteed space maintenance, but only blood clots caused a loss in volume after 5 weeks from surgery.

It is on the basis of these considerations that we believe that the use of the clot is a good natural scaffold but that it needs adequate protection to prevent reabsorption: the titanium foil. 


\section{Clot Management and Titanium Foil: Biological Principles}

In addition to sinus lift protocols, other studies consider the possibility of using the clot as the main filling scaffold in GBR procedures [40-43].

Standard titan foils could be shaped during the surgical procedures or pre-shaped thanks to the CAD-CAM technology that gives a model of the jawbones.

As suggested by Elgalli et al., stiffness and plasticity are the main features of these barriers $[3,25,44-49]$.

Membrane exposition, usually considered as a surgical complication, [8,50-52] is in this case considered as an intentional procedure above all in socket preservation and GBR [53-56].

In the systematic review of Roca-Millan et al., titanium foils demonstrated a higher tolerability in patients compared to non-absorbable membranes and titanium grids [57].

The rationale beyond the use of titanium is clot protection. Tamura et al. [58] implanted titanium barriers in the rabbits' calvaria without filling materials, leaving them exposed. The authors observed the formation of new lamellar and trabecular bone with bone marrow having grown inside the barrier [58].

In order to evaluate the importance of the occlusive effect of the titanium barrier, Yamada et al. [59] applied two titanium barriers, one occlusive and one perforated, indicating that within the occlusive capsules, a predictable mineralized bone matures in the spaces beyond the skeletal envelope [59].

In another study on rabbits, Ezirganlı et al. [60] used autologous blood, deproteinized bovine bone (DBBG) and biphasic calcium phosphate bio-ceramic graft material as fillers in three different controls. Even though no significant differences between fillers were reported, the regeneration of bone tissue was obtained only using clot as a filler; on the contrary, the regenerated tissue obtained using other fillers had inclusions of graft material. Moreover, the authors noticed an improved osteoclastic activity in BCP rather than DBBG [60].

Van Steenberghe et al. [25] conducted their clinical study on patients with severe atrophy of the upper jaw. They were treated with customized titanium occlusive barriers filled with the clot. Follow-up was 12 and 18 months and after the removal of the barriers it was possible to observe large volumes of regenerated bone allowing the implantation of 33 implants. The authors concluded that this innovative technique was highly predictable in the regeneration of large bone defects and was to consider the new gold standard in jaw rehabilitation with implants.

We report on 5 heterogeneous clinical cases to support and demonstrate the previously described characteristics of titan foil and clot. The cases are different from each other because they emphasize the different uses and properties of the titanium barriers and the clot, in different clinical situations and settings.

\section{Case Series}

\subsection{Clinical Case n.1.}

This 45-year-old male patient was scheduled for prosthetic rehabilitation of the posterior maxillary area. After a radiological check, it was decided to proceed with a lateral sinus lift approach (Figure 1a,b).

A full-thickness flap was incised, and a bone window was made. A $25 \times 35 \mathrm{~mm}$ foil was "L" shaped and applied in the window bone to allow its short side to be fixed on the vestibular bone and the long side overturned inside the sinus to maintain the created volume (Figure 2a,b).

The space between the sinus floor and the sinus membrane was filled with blood clot and a second foil was shaped and fixed to vestibular bone in order to separate the cavity from the surrounding soft tissues (Figure 2c). 


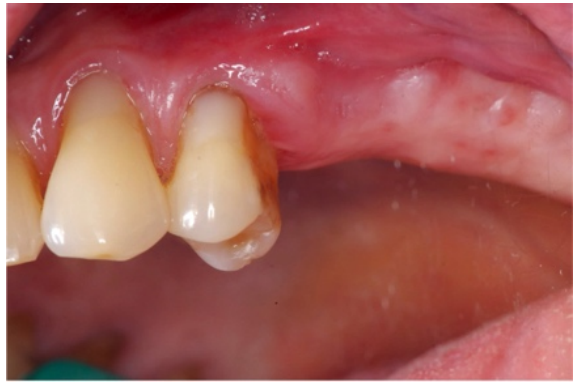

(a)

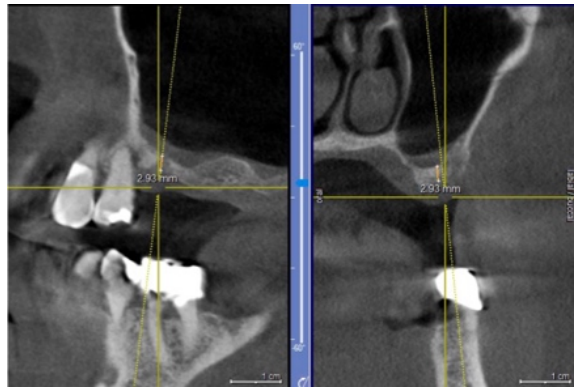

(b)

Figure 1. (a,b): First quadrant clinical aspect and TAC X-ray image.

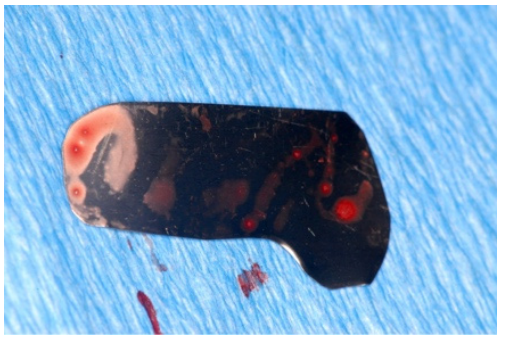

(a)

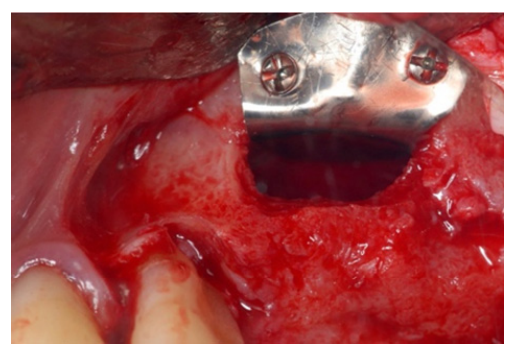

(b)

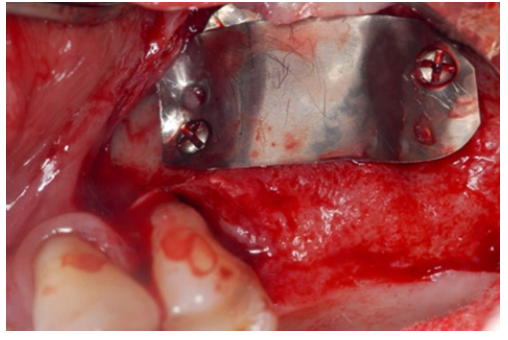

(c)

Figure 2. (a) shaped foil; (b) foil fixed to the bone window; (c) bone surgical site isolation.

Six months later, a full-thickness vestibular flap was made (Figure 3a) to remove the foil barriers and to proceed with the implant insertion (Figure $3 b$ ).

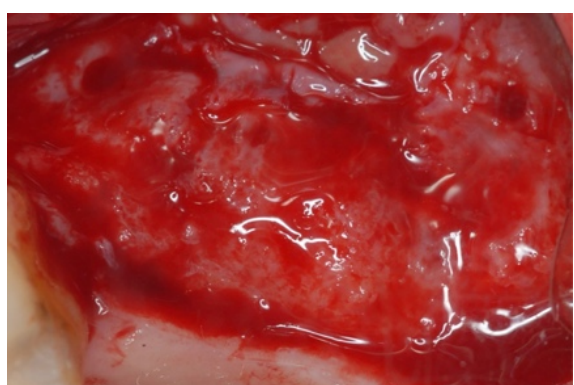

(a)

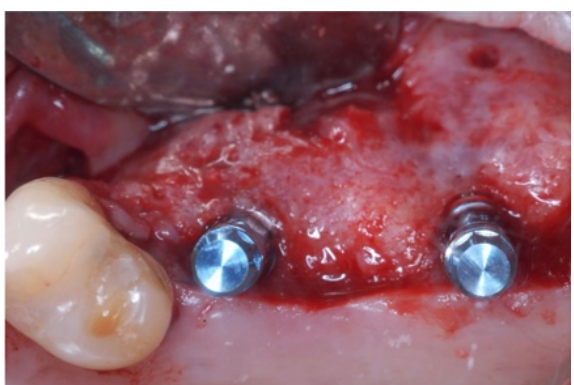

(b)

Figure 3. (a) newly formed bone tissue; (b) implant placement.

The pre-implant CT showed (Figure 4) the new bone volume obtained with the procedure, which was sufficient to allow the implant insertion.

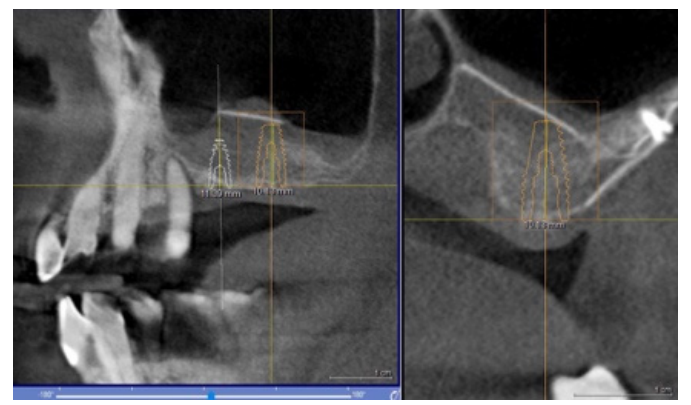

Figure 4. Foil radiographic checks: in evidence the shape of the foil. 
The histological examination of the regenerated bone evidenced the presence of newly generated bone tissue (Figure 5).

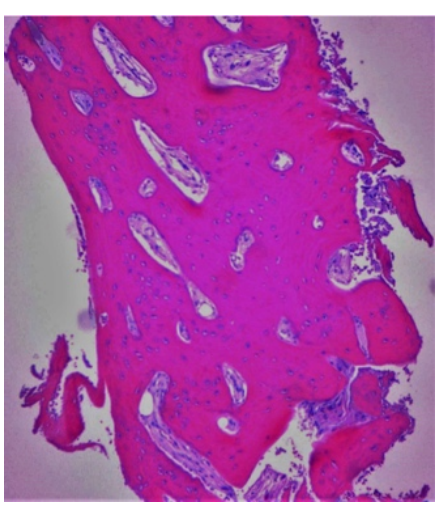

(a)

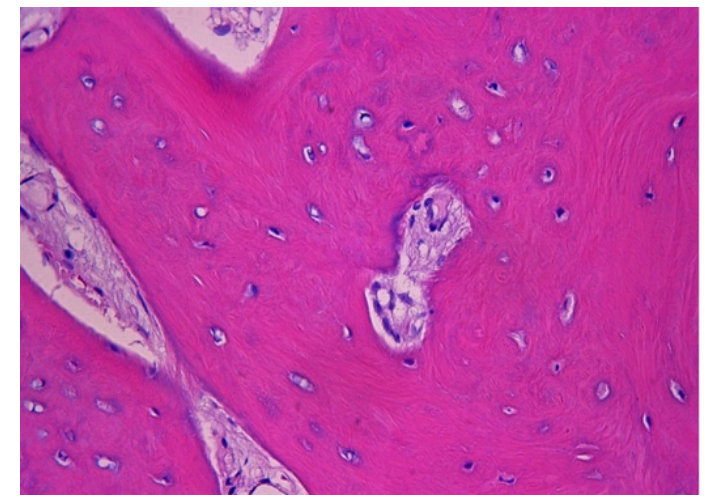

(b)

Figure 5. (a,b) histological examination which confirms the presence of only newly formed bone tissue.

In this case, it is shown how titanium foil could be employed in sinus lift thanks to its ability to maintain the space filled with blood clot.

\subsection{Clinical Case n.2.}

In order to rehabilitate the missing 1.3, an immediate post-extractive implant for tooth 1.3 was planned (Figure $6 a-c)$. Blood clot was collected directly from patients (peripheral venous blood) and placed in a $5 \mathrm{~mL}$ vial. When the clot was thick enough due to coagulation, it was enriched with beta-tricalcium phosphate by rolling it on the surface of tricalcium granules: $1 \mathrm{~g}$ beta-tricalcium phosphate for every $5 \mathrm{~mL}$ of clot (Figure 7). Beta-tricalcium phosphate was chosen to stabilize the clot volume and for its capacity to be reabsorbed [61-63].

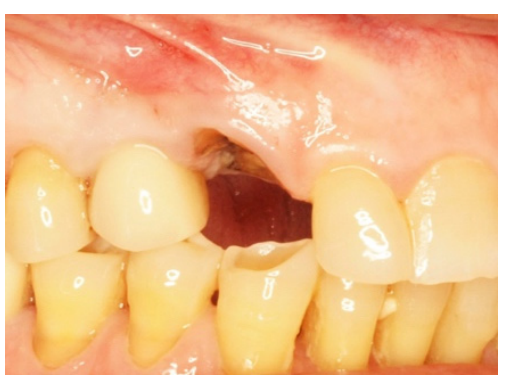

(a)

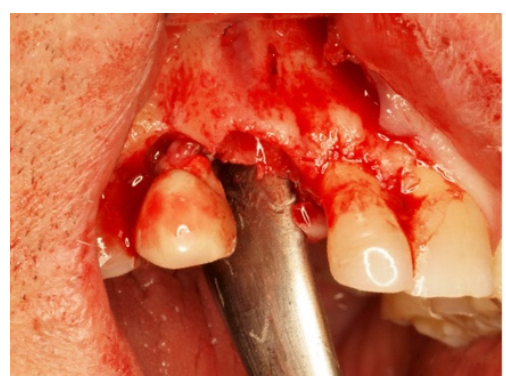

(b)

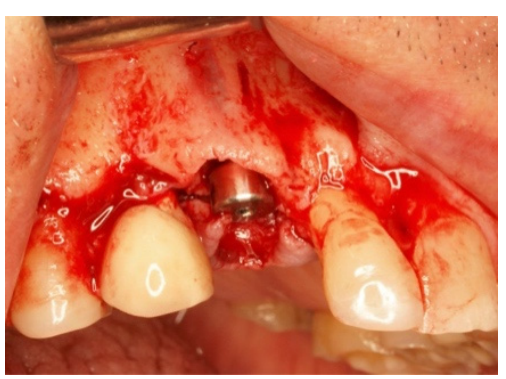

(c)

Figure 6. (a) Edentulous tooth site 13; (b) evaluation of the alveolus; (c) implant insertion.

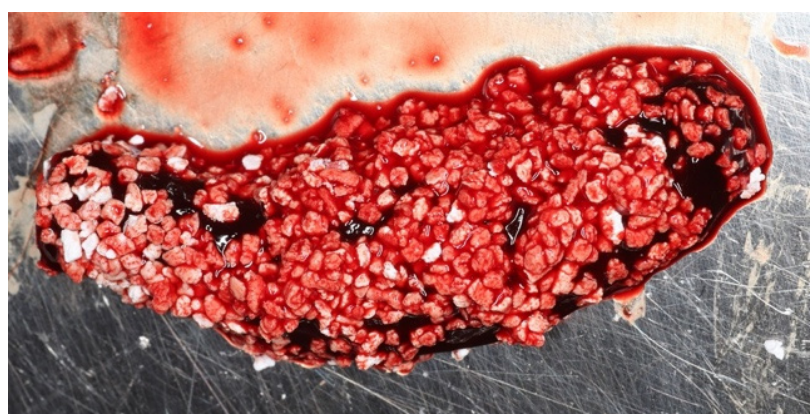

Figure 7. Peripheral blood clot with beta-tricalcium phosphate particles in granules. 
After the implant insertion, the enriched clot was put in the alveolar gap and protected by a shaped intra-operatory titanium foil, fixed with screws on both buccal and palatal walls. It sutured, leaving the foil exposed (Figure $8 \mathrm{a}, \mathrm{b}$ ).

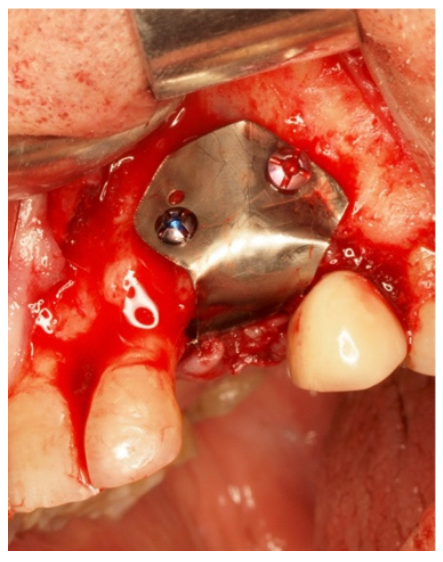

(a)

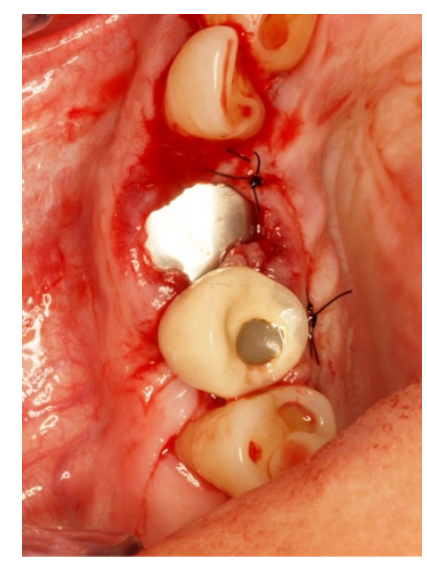

(b)

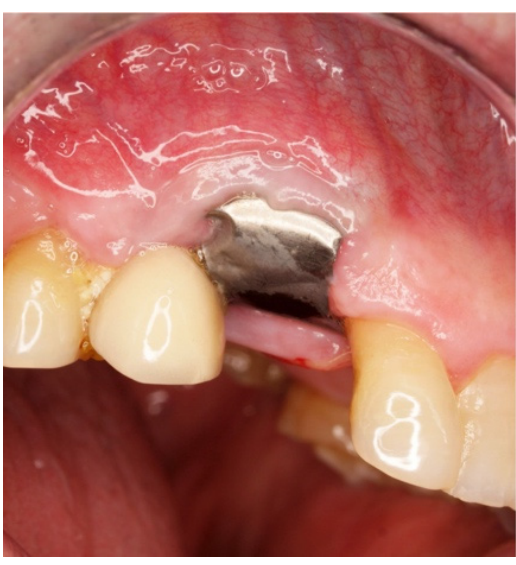

(c)

Figure 8. (a) Protection of the alveolus with titanium foil; (b) titanium foil; (c) follow-up at 6 months.

Six months after surgery, the high quality and stability of soft tissues was observed (Figure 8c).

The titanium barrier was removed and the growth of new bone tissue, even if not completely mature, was observed (Figure 9a). After a further 6 months, we noted how pre-existing keratinized gingiva of keratinized mucosa indicated by the arrow in Figure 9a, contributed to the formation of the adherent gingiva band as shown in Figure $9 \mathrm{~b}$.

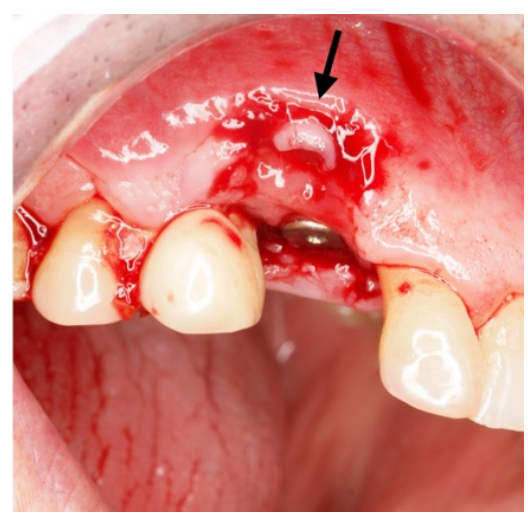

(a)

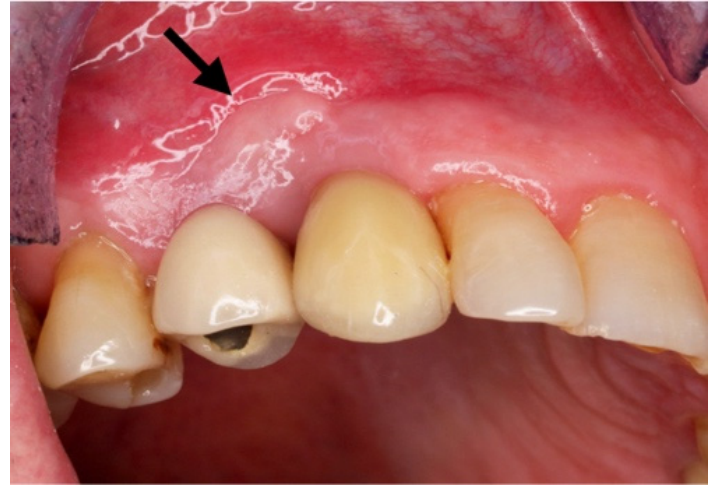

(b)

Figure 9. (a) Flap of keratinized mucosa indicated by the arrow; (b) finalization with a prosthetic crown.

\subsection{Clinical Case n.3.}

In this case, we observed how modern 3D reconstruction techniques can be a good support in regenerative surgery. In fact, starting from dicom files format, obtained with cone-beam computed tomography (CBCT) (Osteophoenix, Erandio-Vizcaya-Spain) it was possible to simulate "ex-ante" the surgical procedure. In addition to the reconstruction of the mandible (Figure 10a), the extraction of molars 4.6 and 4.7 was also simulated.

A titanium foil barrier was preventively designed and prepared in order to shorten surgical time (Figure 10b). In fact, the great advantage in cases like this is that the device does not need to be shaped during the surgical session. 


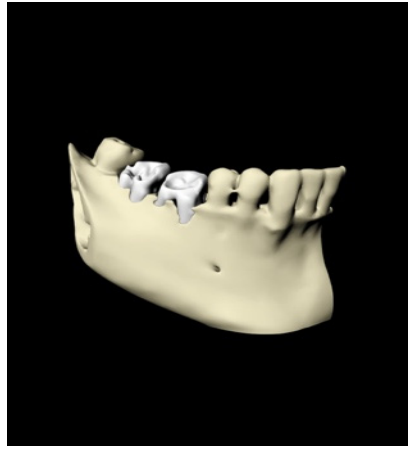

(a)

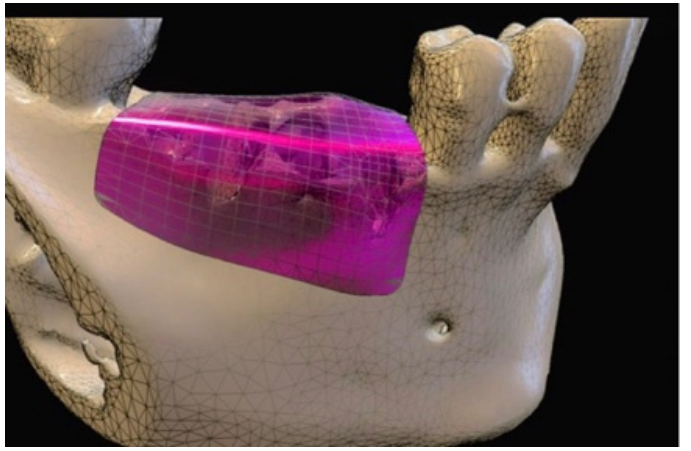

(b)

Figure 10. (a) 3D model of the mandible; (b) Titanium foil digital design.

The surgery protocol was the same as described in the previous case (Figure 11a-e). The extraction of teeth and the simultaneous insertion of the implants was performed in the same session (Figure 11a). The enriched clot (1 $\mathrm{g}$ beta-tricalcium phosphate for every $5 \mathrm{~mL}$ of clot) was protected by the shaped foil fixed with screws (Figure 11b) and its successive removal was at six months (Figure 11c). A further six months were necessary for soft tissue maturation (Figure 11d,e). In this case, the flap of keratinized mucosa, indicated by the white arrow in Figure 11c-e, contributed to the stability of the keratinized mucosa. At the follow-up, the gingival tissue was adequately matured, avoiding further graft of soft tissue (Figure 12).

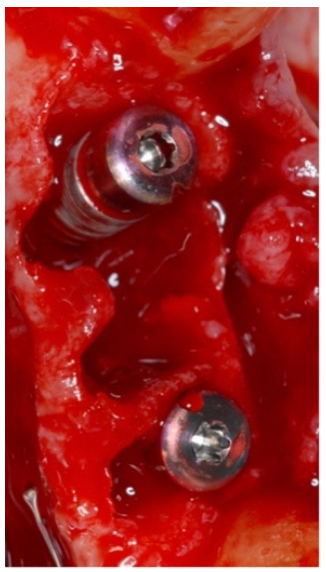

(a)

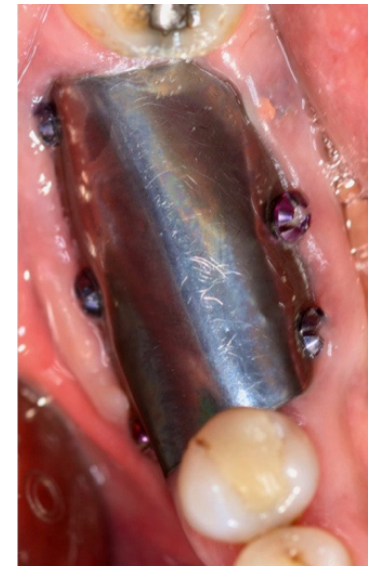

(b)

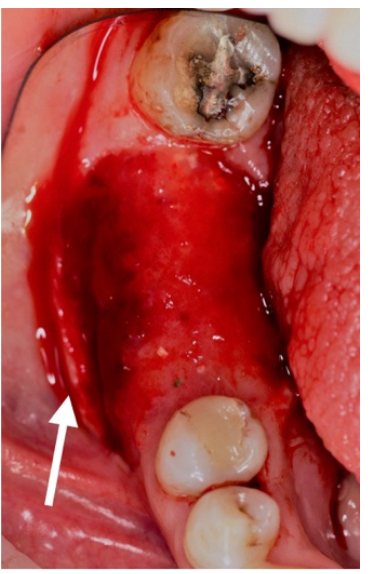

(c)

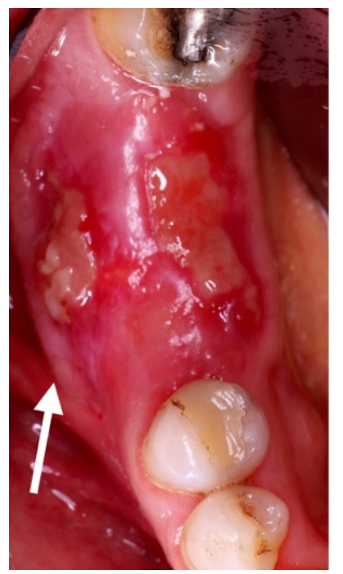

(d)

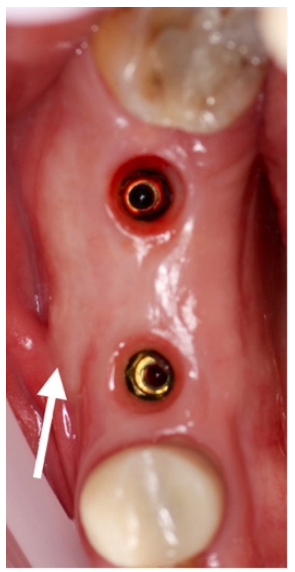

(e)

Figure 11. (a) Avulsion of the teeth and simultaneous insertion of the implants; (b) Use of the enriched clot and cover with the foil blocked with the screws; (c) Removal of the foil at six months; (d) Maturation of the tissues after one week from the withdrawal of the foil; (e) pre-prosthetic situation of implants and mucosa.

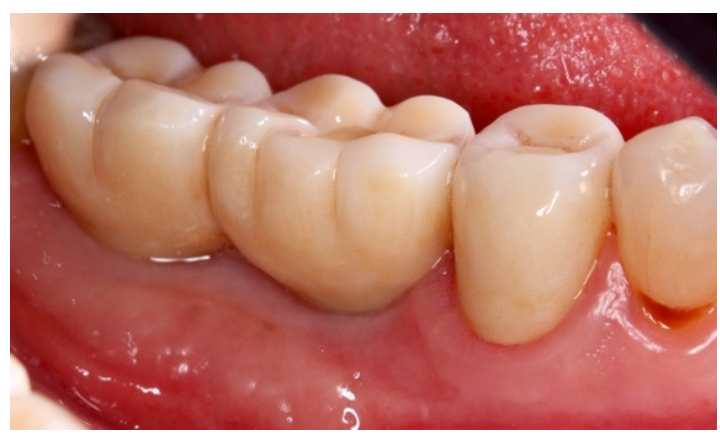

Figure 12. Prosthetic finalization of the case and mucose quality. 


\subsection{Clinical Case n.4.}

In this case, a cystic lesion involving three lower incisors was treated (Figure 13a).

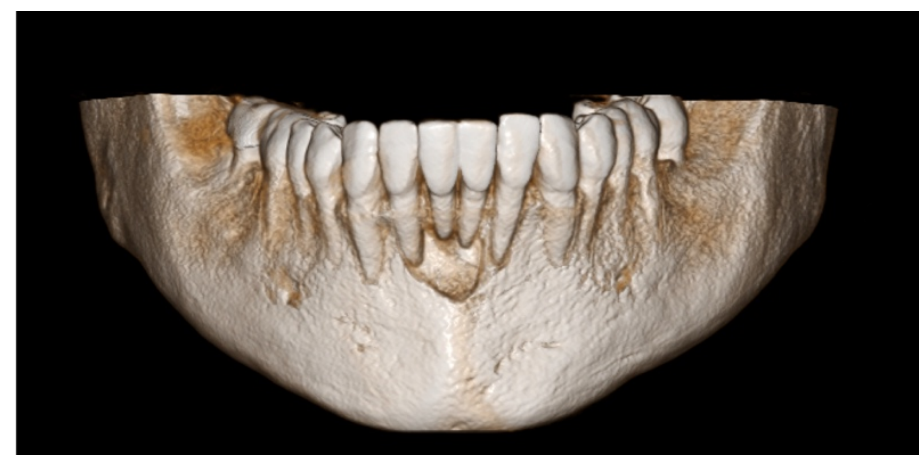

(a)

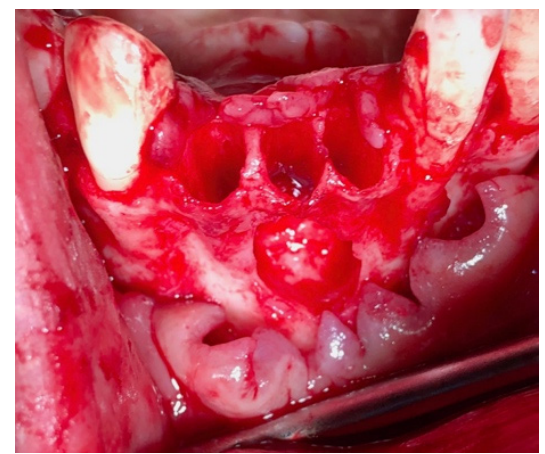

(b)

Figure 13. (a) Cystic lesion between lower incisors; (b) full-thickness flap, extraction of the three incisors and removal of the cyst.

Following a full-thickness flap, three incisors (4.2, 4.1 and 3.1) were extracted (Figure 13b). After a careful curettage of the cyst cavity, collagen sponges were grafted in the cavity. The collagen sponges were wet with surgical site blood (Figure 14a). A titanium foil (Figure 14b) was shaped and positioned and the flap sutured.

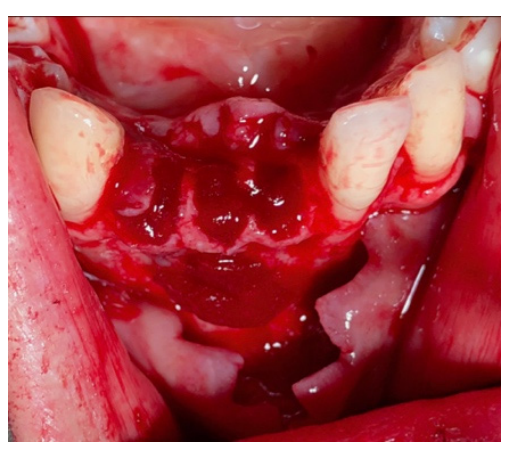

(a)

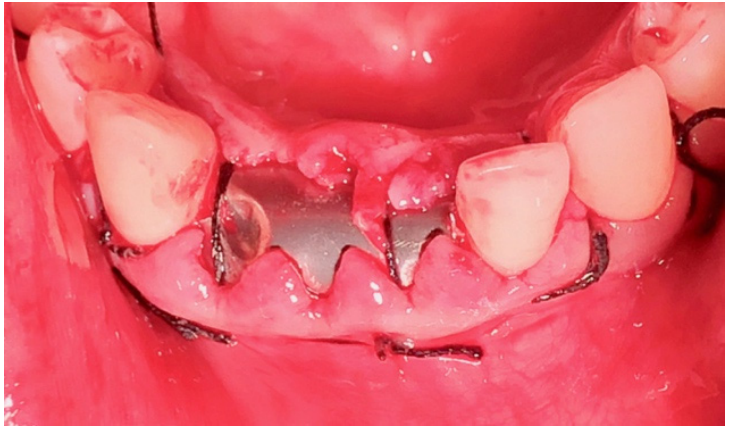

(b)

Figure 14. (a) Extraction site filled with collagen sponges; (b) titanium foil and suture.

At the follow-up, a significant plaque accumulation on the foil surface was observed; nevertheless, there were no significant signs of soft tissue distress (Figure 15).

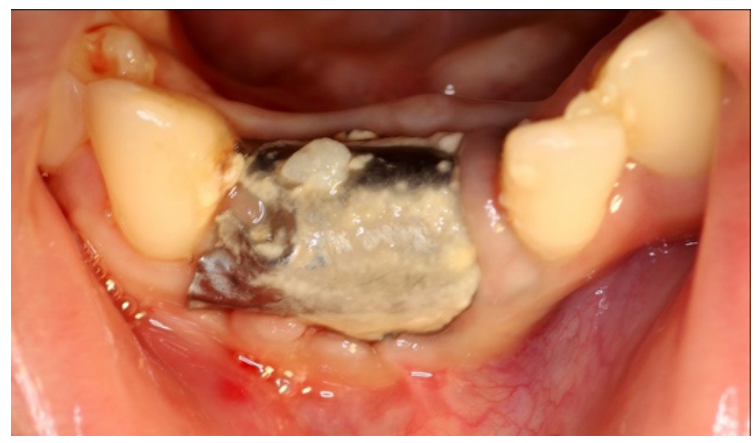

Figure 15. Accumulation of plaque on the foil.

4 months after the surgery, the barrier was withdrawn and, behind it, growth of elastic and thick osteoid tissue was observed (Figure 16a,b). After further 4 months, a CBCT was performed, and the amount of regenerated bone was observed (Figure 17a-d). 


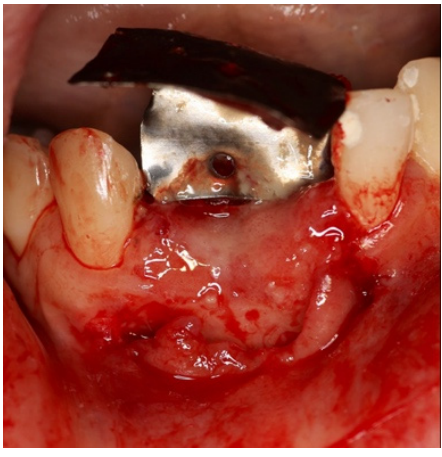

(a)

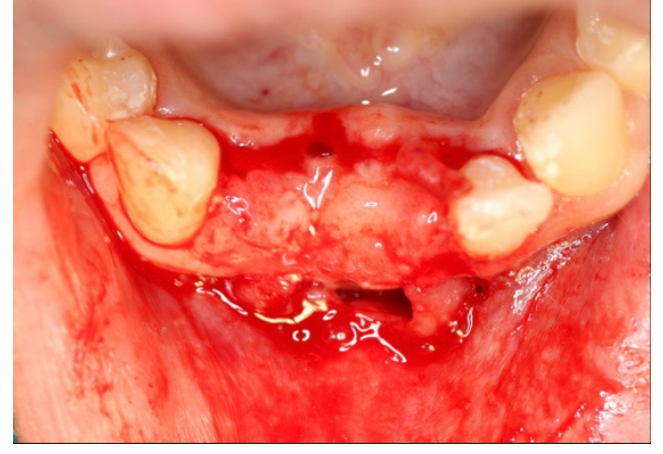

(b)

Figure 16. (a) Removal of titanium foil after 4 months; (b) osteoid tissue with hard but still elastic consistency covered by not-epithelized mucosa.

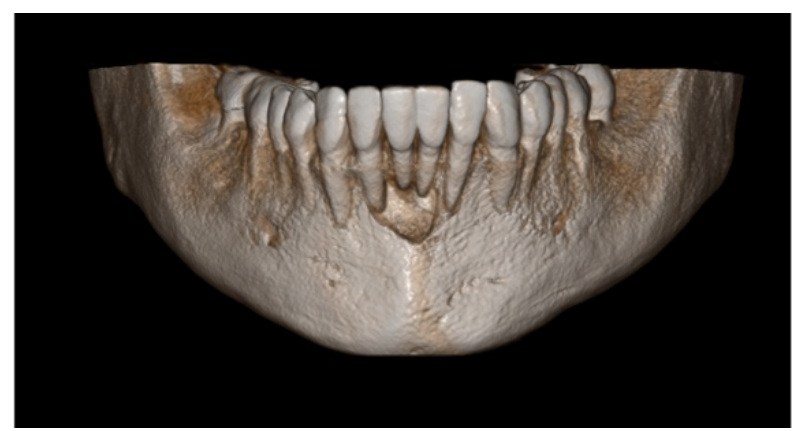

(a)

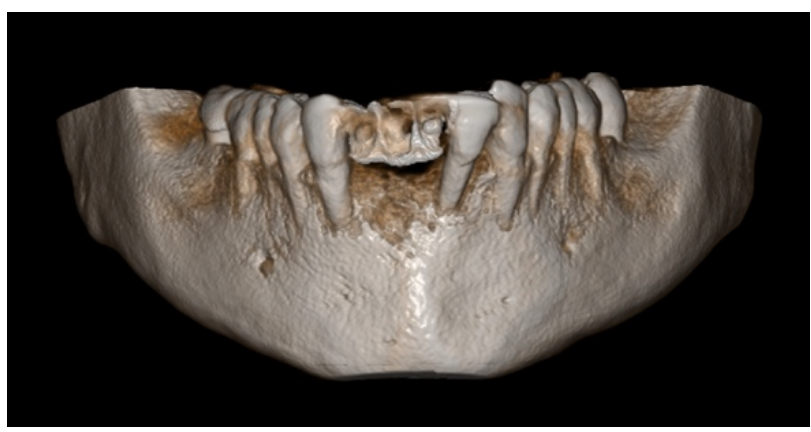

(c)

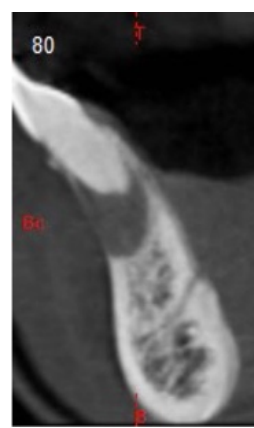

(b)

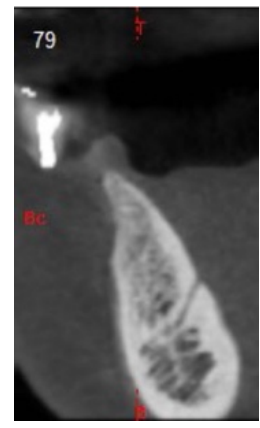

(d)

Figure 17. (a) Initial 3D situation; (b) CBCT of the initial situation; (c) Final CBCT post 3D regeneration after 4 months; (d) X-ray of the situation post regeneration after 4 months.

The patient was prosthetically rehabilitated with additional implants positioned in 4.2 and 3.2 (post-extractive). In this case, we also noted how soft tissues surrounding the regenerated site were mature and stable (Figure 18).

\subsection{Clinical Case n.5.}

In this case, we report a procedure based on biological principles reported by Polimeni et al. [64] and Komman and Robertson about the regenerative properties of the periodontium [65] and surgical procedures, are factors associated to the correct management of the periodontal defects. Wikesjö et al. [66] reported that the extension of the periodontal regenerated area was better in sites treated by occlusive membranes rather than the porous one. Moreover, Luo et al. [67] in an experimental study, reported better outcomes in premolars furcation healing treated with blood clot pointed out the larger regenerative potential of the clot rather than bone-chip. 


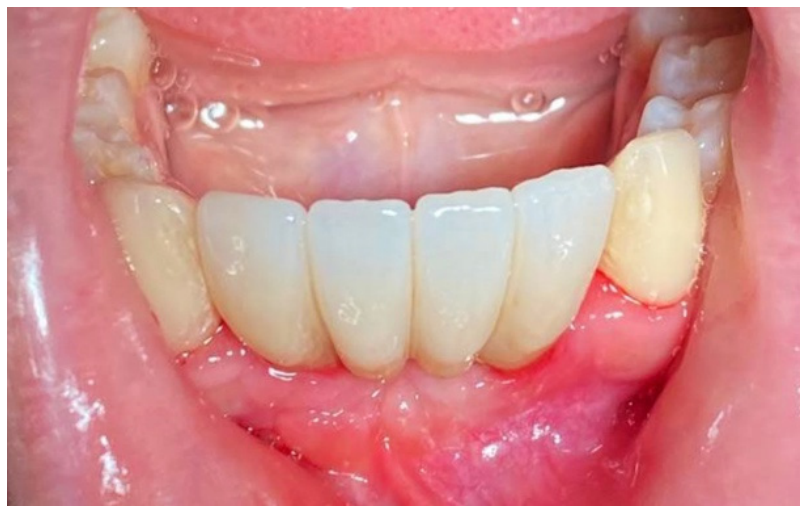

Figure 18. Prosthetic finalization of the case and mucose quality.

In this case of chronic periodontal abscess between teeth 1.7 and 1.6, there was an important buccal and palatal periodontal pocket of $9 \mathrm{~mm}$ with a large resorption of the interdental bone septum. It was decided to extract the tooth 1.7 because of its poor prognosis (Figure 19a,b).

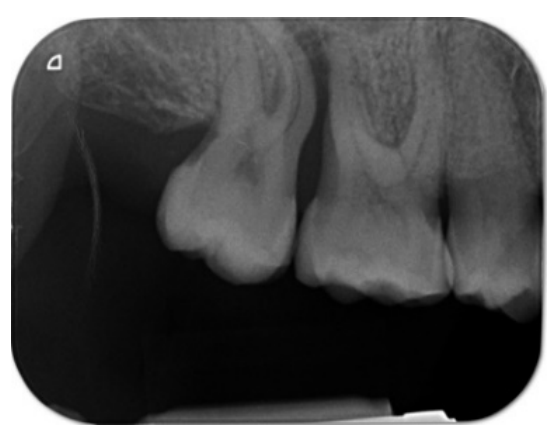

(a)

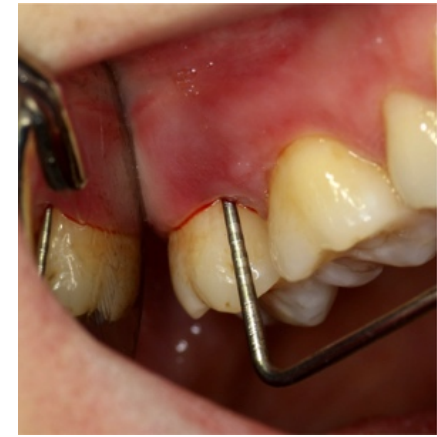

(b)

Figure 19. (a) Periapical radiograph of teeth 1.7, 1.6, 1.5; (b) important probing periodontal mesial root of 1.7 .

A large amount of infected granulation tissue was present in furcation space, between the distal-buccal and palatal root (Figure 20).

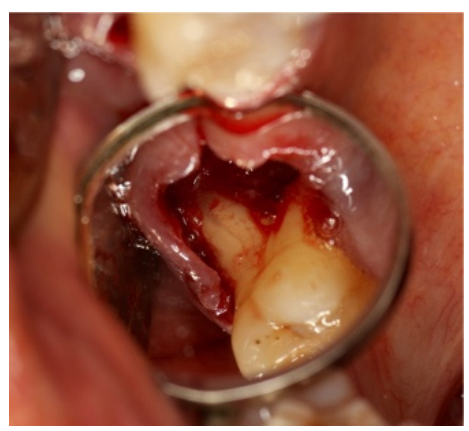

Figure 20. Furcation lesion between the distal buccal root and the palatal tooth 1.6 after 1.7 extraction.

The alveolar cavity and roots were curetted and cleaned with a solution of physiological water and hydrogen peroxide 1:1 and collagen sponges, completely wetted by the blood from the surgical site, were applied and followed by the protective positioning of a shaped foil. 
After three months, the foil was removed (Figure 21a,b) and the roots surface previously exposed, appeared covered by bone.

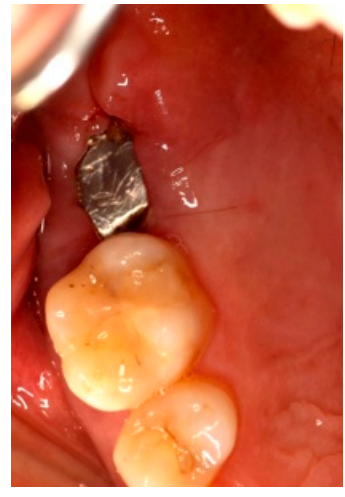

(a)

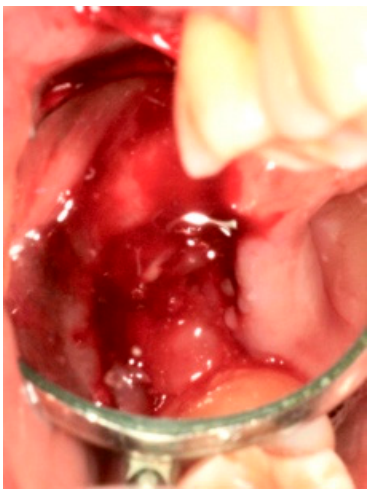

(b)

Figure 21. (a) Removal of sutures after 3 weeks; (b) extensive healing tissue is observed which has completely covered the previously exposed roots.

A Comparative radiological analysis before and after the surgical procedure, showed an increase in the distal bone peak. The gained bone was also maintained after 6 months of follow-up (Figure 22c). After one year (Figure 22d), the distal bone peak was comparable in height with the vestibular one.

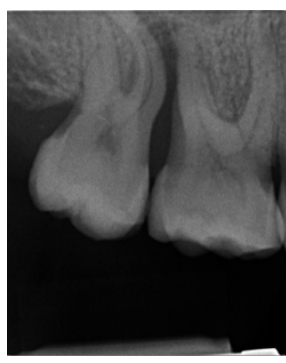

(a)

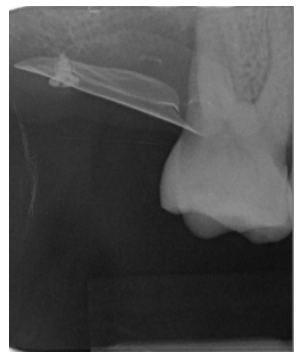

(b)

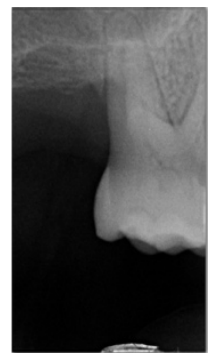

(c)

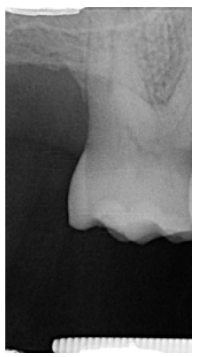

(d)

Figure 22. (a) Initial periapical radiograph; (b) periapical radiograph after foil placement; (c) periapical radio-graph after 6 months; (d) periapical radiograph after one year.

This is a further demonstration of how clot alone (a natural scaffold) induces the best regenerative abilities of the residual bone.

\section{Discussion}

In our case series, we report different clinical situations connected by the common thread of the blood clot. Starting from biological considerations about using blood clots as a scaffold we proceeded to make suggestions for its protection through the use of titanium foil as a barrier.

We evidenced how titanium foil is a biomaterial that is easy to handle, tolerated by the tissues and respectful of the biological processes that guarantee the healing and the formation of new bone tissue. Its association with the clot stabilized by beta-tricalcium phosphate, makes the GBR procedures more predictable.

Moreover, the described biomaterials, have allowed in different and heterogeneous clinical situations, to customize the treatment, according to the anatomical and surgical needs.

Several studies evaluated the differences between occlusive barriers and resorbable membranes and indicated the different use according to the characteristics of each case [68]. In other studies, attention was paid to the bioactive role of the barrier. Other studies stated 
that the barrier guarantees the maintenance of space, allowing selective permeability $[3,5]$. In this way the two compartments (bone defect and soft tissue), separated by the barrier, act in synergy. It is certainly interesting that this will happen in the future, but we are still far from understanding the mechanisms of this interaction as, for example, in the case of the role of periostin $[69,70]$.

As stated in Cucchi et al. [8], in controlled and randomized clinical studies, there are no significant differences between d-PTFE membrane and titanium grids covered by collagen membrane, neither in regenerated bone volume nor in clinical complications. Soldatos et al. [71] supported the theory in which both kinds of membranes have limitations that affect the clinical outcomes. In fact, the most helpful material in exposure is the titanium foil, as reported by Roca-Milan et al. [57]. The use of titanium barriers is increasing in clinical practice $[48,49]$. The biological behavior of the mucosa around the surfaces of dental implants is well known. The soft tissues tend to create attached epithelium with the titanium surface, in an area of about $2 \mathrm{~mm}$ apically from the soft tissue edge [72]. For these reasons it is possible to use a highly bio-compatible and inert material that can avoid mucosal alterations in intentional and accidental exposition. In fact, by following an appropriate hygiene protocol, it is possible to control plaque formation [73].

Titanium barriers are the best solution, due to versatility and manageable features. These features assure shorter and better surgery and wound healing practices.

In a comparative study between bone graft and GBR performed with titanium foils and clot alone, Molly et al. [45] analyzed the gained bone volume obtained with two different techniques: bone grafts and GBR made with Ti barriers with the clot as a filler. Dental implants were subsequently placed in the same sites. The bone volume obtained with the barriers was lower, however the resorption of peri-implant marginal bone proved to be more stable over time than the implants inserted into the grafts.

The two main critical issues in the use of clot are the scarce dimensional stability resulting from contractions, and the interaction between platelets and the surrounding environment [74].

Platelet contractions re-shape fibrin networks by improving the density and stiffness of the blood clot. Fundamentally, platelets compact the fibrin network (i.e., densify the fibrin network by pulling the fibers transversely to their longitudinal axes). New observations about platelet contraction in clot showed potential implications in the biological application of cell motility [75].

Since platelets have the property of mechanosensing (the ability to recognize substrates with variable stiffness and activate accordingly) it is possible to exploit this property to modulate the density and stiffness of the clot itself [76].

These claims justify why Molly et al. found less bone volume at the end of their experiment. Based on these claims, we can assume how important it is to use clot in association with a filler that, through its biological activity and without interfering with the clot, can confer a main support function expressing those inherent properties peculiar to the clot-scaffold. In our opinion, beta-tricalcium phosphate is the best candidate as filler to associate with the blood clot.

\section{Conclusions}

Titanium foil represents an excellent barrier that is useful in GBR, and it is also the best choice to protect the clot, due to its biocompatibility, handling and mechanical strength properties.

Furthermore, if the clot alone induces a higher quality bone at the expense of bone volume, we hope that tissue engineering will discover a suitable material to support the clot and/or act as the clot. We now think that the clot is the model to inspire future studies.

Author Contributions: Conceptualization, L.M. and M.P.; manuscript preparation and revisions, L.M., F.C., D.L. and F.L.P., coordination and supervision of the project, L.M. All authors have read and agreed to the published version of the manuscript. 
Funding: This research received no external funding. Osteophoenix Italia s.r.l.s. supported the fees for the article publication.

Institutional Review Board Statement: Not applicable.

Informed Consent Statement: Informed consent was obtained from all subjects involved in the study. Written informed consent has been obtained from the patient(s) to publish this paper.

Data Availability Statement: The data presented in this study are available on request from Lucio Milillo (lmilillo1@tin.it). The data are not publicly available due to Italian law about personal privacy (D. lgs. 30 June 2003, n. 196).

Acknowledgments: The authors would like to thank David Yu, Carlos Pena and Zelai Cabañas for making available clinical cases 1, 2 and 3. The authors also thank Sherdil Singh Bullar and Mauricio Lizarazo for their technical support.

Conflicts of Interest: The authors declare no conflict of interest.

\section{References}

1. Gultekin, B.A.; Bedeloglu, E.; Kose, T.E.; Mijiritsky, E. Comparison of Bone Resorption Rates after Intraoral Block Bone and Guided Bone Regeneration Augmentation for the Reconstruction of Horizontally Deficient Maxillary Alveolar Ridges. BioMed Res. Int. 2016, 2016, 1-9. [CrossRef] [PubMed]

2. Pistilli, R.; Checchi, V.; Sammartino, G.; Simion, M.; Felice, P. Safe New Approach to the Lingual Flap Management in Mandibular Augmentation Procedures: The Digitoclastic Technique. Implant Dent. 2017, 26, 790-795. [CrossRef]

3. Elgali, I.; Omar, O.; Dahlin, C.; Thomsen, P. Guided bone regeneration: Materials and biological mechanisms revisited. Eur. J. Oral Sci. 2017, 125, 315-337. [CrossRef] [PubMed]

4. Ronda, M.; Stacchi, C. A Novel Approach for the Coronal Advancement of the Buccal Flap. Int. J. Periodontics Restor. Dent. 2015, 35, 795-801. [CrossRef]

5. Omar, O.; Elgali, I.; Dahlin, C.; Thomsen, P. Barrier membranes: More than the barrier effect? J. Clin. Periodontol. 2019, 46 (Suppl. 21), 103-123. [CrossRef] [PubMed]

6. Windisch, P.; Martin, A.; Shahbazi, A.; Molnar, B. Reconstruction of horizontovertical alveolar defects. Presentation of a novel split-thickness flap design for guided bone regeneration: A case report with 5-year follow-up. Quintessence Int. 2017, 48, 535-547. [CrossRef]

7. Windisch, P.; Orban, K.; Salvi, G.E.; Sculean, A.; Molnar, B. Vertical-guided bone regeneration with a titanium-reinforced d-PTFE membrane utilizing a novel split-thickness flap design: A prospective case series. Clin. Oral Investig. 2021, 25, 2969-2980. [CrossRef]

8. Cucchi, A.; Vignudelli, E.; Napolitano, A.; Marchetti, C.; Corinaldesi, G. Evaluation of complication rates and vertical bone gain after guided bone regeneration with non-resorbable membranes versus titanium meshes and resorbable membranes. A randomized clinical trial. Clin. Implant Dent. Relat. Res. 2017, 19, 821-832. [CrossRef]

9. Jepsen, S.; Schwarz, F.; Cordaro, L.; Derks, J.; Hämmerle, C.H.F.; Heitz-Mayfield, L.J.; Hernández-Alfaro, F.; Meijer, H.J.A.; Naenni, N.; Ortiz-Vigón, A.; et al. Regeneration of alveolar ridge defects. Consensus report of group 4 of the 15th European Workshop on Periodontology on Bone Regeneration. J. Clin. Periodontol. 2019, 46 (Suppl. 21), 277-286. [CrossRef]

10. Patterson, J.; Martino, M.; Hubbell, J.A. Biomimetic materials in tissue engineering. Mater. Today 2010, 13, 14-22. [CrossRef]

11. Grayson, W.L.; Martens, T.P.; Eng, G.M.; Radisic, M.; Vunjak-Novakovic, G. Biomimetic approach to tissue engineering. Semin. Cell Dev. Biol. 2009, 20, 665-673. [CrossRef]

12. Yildirim, M.; Spiekermann, H.; Biesterfeld, S.; Edelhoff, D. Maxillary sinus augmentation using xenogenic bone substitute material Bio-Oss ${ }^{\circledR}$ in combination with venous blood: A histologic and histomorphometric study in humans. Clin. Oral Implant. Res. 2000, 11, 217-229. [CrossRef] [PubMed]

13. Traini, T.; Valentini, P.; Iezzi, G.; Piattelli, A. A Histologic and Histomorphometric Evaluation of Anorganic Bovine Bone Retrieved 9 Years After a Sinus Augmentation Procedure. J. Periodontol. 2007, 78, 955-961. [CrossRef]

14. Guarnieri, R.; Belleggia, F.; DeVillier, P.; Testarelli, L. Histologic and Histomorphometric Analysis of Bone Regeneration with Bovine Grafting Material after 24 Months of Healing. A Case Report. J. Funct. Biomater. 2018, 9, 48. [CrossRef] [PubMed]

15. Nyström, E.; Nilson, H.; Gunne, J.; Lundgren, S. A 9-14 year follow-up of onlay bone grafting in the atrophic maxilla. Int. J. Oral Maxillofac. Surg. 2009, 38, 111-116. [CrossRef] [PubMed]

16. Burchardt, H. The Biology of Bone Graft Repair. Clin. Orthop. Relat. Res. 1983, 174, 28-42. [CrossRef]

17. Widmark, G.; Andersson, B.; Ivanoff, C.-J. Mandibular bone graft in the anterior maxilla for single-tooth implants: Presentation of a surgical method. Int. J. Oral Maxillofac. Surg. 1997, 26, 106-109. [CrossRef]

18. Stricker, A.; Jacobs, R.; Maes, F.; Fluegge, T.; Vach, K.; Fleiner, J. Resorption of retromolar bone grafts after alveolar ridge augmentation-Volumetric changes after 12 months assessed by CBCT analysis. Int. J. Implant. Dent. 2021, 7, 1-7. [CrossRef]

19. Chiapasco, M.; Casentini, P.; Zaniboni, M. Bone augmentation procedures in implant dentistry. Int. J. Oral Maxillofac. Implant. 2009, 24, 237-260. 
20. Chiapasco, M.; Zaniboni, M.; Rimondini, L. Autogenous onlay bone grafts vs. alveolar distraction osteogenesis for the correction of vertically deficient edentulous ridges: A 2-4-year prospective study on humans. Clin. Oral Implant. Res. 2007, 18, 432-440. [CrossRef]

21. Murray, G.; Holden, R.; Roschlau, W. Experimental and clinical study of new growth of bone in a cavity. Am. J. Surg. 1957, 93, 385-387. [CrossRef]

22. Melcher, A.H.; Dreyer, C.J. Protection of the Blood Clot in Healing Circumscribed Bone Defects. J. Bone Jt. Surg. Br. Vol. 1962, 44, 424-430. [CrossRef]

23. Wang, X.; Friis, T.; Glatt, V.; Crawford, R.; Xiao, Y. Structural properties of fracture haematoma: Current status and future clinical implications. J. Tissue Eng. Regen. Med. 2017, 11, 2864-2875. [CrossRef]

24. Lundgren, S.; Andersson, S.; Sennerby, L. Spontaneous Bone Formation in the Maxillary Sinus after Removal of a Cyst: Coincidence or Consequence? Clin. Implant Dent. Relat. Res. 2003, 5, 78-81. [CrossRef]

25. Van Steenberghe, D.; Johansson, C.; Quirynen, M.; Molly, L.; Albrektsson, T.; Naert, I. Bone augmentation by means of a stiff occlusive titanium barrier. Clin. Oral Implant. Res. 2003, 14, 63-71. [CrossRef] [PubMed]

26. Chipaila, N.; Marini, R.; Sfasciotti, G.L.; Cielo, A.; Bonanome, L.; Monaco, A. Graftless sinus augmentation technique with contextual placement of implants: A case report. J. Med. Case Rep. 2014, 8, 437. [CrossRef]

27. Gomes, P.D.S.; Daugela, P.; Poskevicius, L.; Mariano, L.; Fernandes, M.H. Molecular and Cellular Aspects of Socket Healing in the Absence and Presence of Graft Materials and Autologous Platelet Concentrates: A Focused Review. J. Oral Maxillofac. Res. 2019, 10, e2. [CrossRef]

28. Kolar, P.; Schmidt-Bleek, K.; Schell, H.; Gaber, T.; Toben, D.; Schmidmaier, G.; Perka, C.; Buttgereit, F.; Duda, G.N. The Early Fracture Hematoma and Its Potential Role in Fracture Healing. Tissue Eng. Part B Rev. 2010, 16, 427-434. [CrossRef] [PubMed]

29. Scala, A.; Lang, N.P.; Schweikert, M.T.; De Oliveira, J.A.; Rangel-Garcia, I.; Botticelli, D. Sequential healing of open extraction sockets. An experimental study in monkeys. Clin. Oral Implant. Res. 2013, 25, 288-295. [CrossRef]

30. Li, J.; Chen, M.; Chen, M.; Wei, X.; Hao, Y.; Wang, J. Evaluation of 3D-Printed Polycaprolactone Scaffolds Coated with Freeze-Dried Platelet-Rich Plasma for Bone Regeneration. Materials 2017, 10, 831. [CrossRef] [PubMed]

31. Batas, L.; Tsalikis, L.; Stavropoulos, A. PRGF as adjunct to DBB in maxillary sinus floor augmentation: Histological results of a pilot split-mouth study. Int. J. Implant. Dent. 2019, 5, 14. [CrossRef] [PubMed]

32. Fernández-Medina, T.; Vaquette, C.; Ivanovski, S. Systematic Comparison of the Effect of Four Clinical-Grade Platelet Rich Hemoderivatives on Osteoblast Behaviour. Int. J. Mol. Sci. 2019, 20, 6243. [CrossRef]

33. Shiu, H.T.; Goss, B.; Lutton, C.; Crawford, R.; Xiao, Y. Formation of Blood Clot on Biomaterial Implants Influences Bone Healing. Tissue Eng. Part B Rev. 2014, 20, 697-712. [CrossRef] [PubMed]

34. Gersh, K.C.; Nagaswami, C.; Weisel, J.W. Fibrin network structure and clot mechanical properties are altered by incorporation of erythrocytes. Thromb. Haemost. 2009, 102, 1169-1175. [CrossRef]

35. Thor, A.; Rasmusson, L.; Wennerberg, A.; Thomsen, P.; Hirsch, J.-M.; Nilsson, B.; Hong, J. The role of whole blood in thrombin generation in contact with various titanium surfaces. Biomaterials 2007, 28, 966-974. [CrossRef]

36. Lundgren, S.; Andersson, S.; Gualini, F.; Sennerby, L. Bone reformation with sinus membrane elevation: A new surgical technique for maxillary sinus floor augmentation. Clin. Implant. Dent. Relat. Res. 2004, 6, 165-173. [CrossRef]

37. Lundgren, S.; Cricchio, G.; Palma, V.C.; Salata, L.A.; Sennerby, L. Sinus membrane elevation and simultaneous insertion of dental implants: A new surgical technique in maxillary sinus floor augmentation. Periodontol. 2000 2008, 47, 193-205. [CrossRef]

38. Riben, C.; Thor, A. Follow-Up of the Sinus Membrane Elevation Technique for Maxillary Sinus Implants without the Use of Graft Material. Clin. Implant. Dent. Relat. Res. 2015, 18, 895-905. [CrossRef] [PubMed]

39. Lambert, F.; Leonard, A.; Drion, P.; Sourice, S.; Layrolle, P.; Rompen, E. Influence of space-filling materials in subantral bone augmentation: Blood clot vs. autogenous bone chips vs. bovine hydroxyapatite. Clin. Oral Implant. Res. 2010, 22, 538-545. [CrossRef]

40. Leghissa, G.C.; Zaffe, D.; Assenza, B.; Botticelli, A.R. Guided bone regeneration using titanium grids: Report of 10 cases. Clin. Oral Implant. Res. 1999, 10, 62-68. [CrossRef]

41. Diès, F.; Etienne, D.; Abboud, N.B.; Ouhayoun, J.P. Bone regeneration in extraction sites after immediate placement of an e-PTFE membrane with or without a biomaterial. A report on 12 consecutive cases. Clin. Oral Implant. Res. 1996, 7, 277-285. [CrossRef] [PubMed]

42. Mattout, P.; Nowzari, H. Clinical evaluation of guided bone regeneration at exposed parts of Branemark dental implants with and without bone allograft. Clin. Oral Implant. Res. 1995, 6, 189-195. [CrossRef]

43. Retzepi, M.; Donos, N. Guided Bone Regeneration: Biological principle and therapeutic applications. Clin. Oral Implant. Res. 2010, 21, 567-576. [CrossRef]

44. Gaggl, A.; Schultes, G. Titanium Foil-Guided Tissue Regeneration in the Treatment of Periimplant Bone Defects. Implant. Dent. 1999, 8, 368-375. [CrossRef]

45. Molly, L.; Quirynen, M.; Michiels, K.; Van Steenberghe, D. Comparison between jaw bone augmentation by means of a stiff occlusive titanium membrane or an autologous hip graft: A retrospective clinical assessment. Clin. Oral Implant. Res. 2006, 17, 481-487. [CrossRef] [PubMed]

46. Beltrán, V.; Engelke, W.; Fuentes, R.; Decco, O.; Prieto, R.; Wilckens, M.; Borie, E. Bone Augmentation with Occlusive Barriers and Cortical Particulate Allograft in Transverse Maxillary Defects: A Pilot Study. Int. J. Morphol. 2014, 32, 364-368. [CrossRef] 
47. Engelke, W.; Deccó, O.; Cura, A.C.; Borie, E.; Beltrán, V. Rigid occlusive titanium barriers for alveolar bone augmentation: Two reports with 24-month follow-up. Int. J. Clin. Exp. Med. 2014, 7, 1160-1165.

48. Bassi, M.A.; Andrisani, C.; Lico, S.; Ormanier, Z.; Ottria, L.; Gargari, M. Guided bone regeneration via a preformed titanium foil: Clinical, histological and histomorphometric outcome of a case series. ORAL Implant. 2016, 9, 164-174. [CrossRef]

49. Perret, F.; Romano, F.; Ferrarotti, F.; Aimetti, M. Occlusive Titanium Barrier for Immediate Bone Augmentation of Severely Resorbed Alveolar Sockets with Secondary Soft Tissue Healing: A 2-Year Case Series. Int. J. Periodontics Restor. Dent. 2019, 39, 97-105. [CrossRef] [PubMed]

50. Garcia, J.; Dodge, A.; Luepke, P.; Wang, H.-L.; Kapila, Y.; Lin, G.-H. Effect of membrane exposure on guided bone regeneration: A systematic review and meta-analysis. Clin. Oral Implant. Res. 2018, 29, 328-338. [CrossRef] [PubMed]

51. Lim, G.; Lin, G.-H.; Monje, A.; Chan, H.-L.; Wang, H.-L. Wound Healing Complications Following Guided Bone Regeneration for Ridge Augmentation: A Systematic Review and Meta-Analysis. Int. J. Oral Maxillofac. Implant. 2018, 33, 41-50. [CrossRef] [PubMed]

52. Kim, Y.-K.; Ku, J.-K. Guided bone regeneration. J. Korean Assoc. Oral Maxillofac. Surg. 2020, 46, 361-366. [CrossRef]

53. Laurito, D.; Lollobrigida, M.; Gianno, F.; Bosco, S.; Lamazza, L.; De Biase, A. Alveolar Ridge Preservation with nc-HA and d-PTFE Membrane: A Clinical, Histologic, and Histomorphometric Study. Int. J. Periodontics Restor. Dent. 2017, 37, 283-290. [CrossRef] [PubMed]

54. Iorio-Siciliano, V.; Blasi, A.; Nicolò, M.; Iorio-Siciliano, A.; Riccitiello, F.; Ramaglia, L. Clinical Outcomes of Socket Preservation Using Bovine-Derived Xenograft Collagen and Collagen Membrane Post-Tooth Extraction: A 6-Month Randomized Controlled Clinical Trial. Int. J. Periodontics Restor. Dent. 2017, 37, e290-e296. [CrossRef]

55. Kim, S.-Y.; Kim, Y.-K.; Kim, H.-S.; Yun, P.-Y.; Kim, S.-G.; Choi, Y.-H. Extraction socket sealing using palatal gingival grafts and resorbable collagen membranes. Maxillofac. Plast. Reconstr. Surg. 2017, 39, 39. [CrossRef] [PubMed]

56. Rathnayake, N.; Trajkovski, B.; Rahman, B.; Zafiropoulos, G.G. Clinical Applications and Outcomes of non-resorbable Polytetrafluoroethylene (PTFE) Membranes in Guided Bone Regeneration. J. Int. Dent. Med. Res. 2019, 12, 1626-1635.

57. Roca-Millan, E.; Jané-Salas, E.; Estrugo-Devesa, A.; López-López, J. Evaluation of Bone Gain and Complication Rates after Guided Bone Regeneration with Titanium Foils: A Systematic Review. Materials 2020, 13, 5346. [CrossRef] [PubMed]

58. Tamura, T.; Fukase, Y.; Goke, E.; Yamada, Y.; Sato, S.; Nishiyama, M.; Ito, K. Three-dimensional evaluation for augmented bone using guided bone regeneration. J. Periodontal Res. 2005, 40, 269-276. [CrossRef]

59. Yamada, Y.; Nanba, K.; Ito, K. Effects of occlusiveness of a titanium cap on bone generation beyond the skeletal envelope in the rabbit calvarium. Clin. Oral Implant. Res. 2003, 14, 455-463. [CrossRef] [PubMed]

60. Ezirganlı, Ş.; Polat, S.; Barıs, E.; Tatar, İ.; Çelik, H.H. Comparative investigation of the effects of different materials used with a titanium barrier on new bone formation. Clin. Oral Implant. Res. 2013, 24, 312-319. [CrossRef] [PubMed]

61. Arbez, B.; Manero, F.; Mabilleau, G.; Libouban, H.; Chappard, D. Human macrophages and osteoclasts resorb $\beta$-tricalcium phosphate in vitro but not mouse macrophages. Micron 2019, 125, 102730. [CrossRef] [PubMed]

62. Pascaretti-Grizon, F.; Guillaume, B.; Terranova, L.; Arbez, B.; Libouban, H.; Chappard, D. Maxillary Sinus Lift with BetaTricalcium Phosphate $(\beta-\mathrm{TCP})$ in Edentulous Patients: A Nanotomographic and Raman Study. Calcif. Tissue Int. 2017, 101, 280-290. [CrossRef]

63. Murai, M.; Sato, S.; Fukase, Y.; Yamada, Y.; Komiyama, K.; Ito, K. Effects of Different Sizes of $\beta$-tricalcium Phosphate Particles on Bone Augmentation within a Titanium Cap in Rabbit Calvarium. Dent. Mater. J. 2006, 25, 87-96. [CrossRef] [PubMed]

64. Polimeni, G.; Xiropaidis, A.V.; Wikesjo, U.M.E. Biology and principles of periodontal wound healing/regeneration. Periodontol. 2000 2006, 41, 30-47. [CrossRef] [PubMed]

65. Kornman, K.S.; Robertson, P.B. Fundamental principles affecting the outcomes of therapy for osseous lesions. Periodontol. 2000 2000, 22, 22-43. [CrossRef] [PubMed]

66. Wikesjö, U.M.E.; Lim, W.H.; Thomson, R.C.; Hardwick, W.R. Periodontal repair in dogs: Gingival tissue occlusion, a critical requirement for GTR? J. Clin. Periodontol. 2003, 30, 655-664. [CrossRef]

67. Luo, J.; Xu, J.; Cai, J.; Wang, L.; Sun, Q.; Yang, P. The In Vitro and In Vivo Osteogenic Capability of the Extraction Socket-Derived Early Healing Tissue. J. Periodontol. 2016, 87, 1057-1066. [CrossRef] [PubMed]

68. Naung, N.Y.; Shehata, E.; Van Sickels, J.E. Resorbable Versus Nonresorbable Membranes: When and Why? Dent. Clin. N. Am. 2019, 63, 419-431. [CrossRef]

69. Kudo, A. Periostin in Bone Biology. Adv. Exp. Med. Biol. 2019, 1132, 43-47. [CrossRef] [PubMed]

70. Groeneveldt, L.C.; Herpelinck, T.; Maréchal, M.; Politis, C.; Van Ijcken, W.F.J.; Huylebroeck, D.; Geris, L.; Mulugeta, E.; Luyten, F.P. The Bone-Forming Properties of Periosteum-Derived Cells Differ Between Harvest Sites. Front. Cell Dev. Biol. 2020, Nov 25;8, 554984. [CrossRef]

71. Soldatos, N.K.; Stylianou, P.; Koidou, V.P.; Angelov, N.; Yukna, R.; Romanos, G.E. Limitations and options using resorbable versus nonresorbable membranes for successful guided bone regeneration. Quintessence Int. 2017, 48, 131-147. [CrossRef]

72. Ivanovski, S.; Lee, R. Comparison of peri-implant and periodontal marginal soft tissues in health and disease. Periodontol. 2000 2018, 76, 116-130. [CrossRef] [PubMed]

73. Bunk, D.; Eisenburger, M.; Häckl, S.; Eberhard, J.; Stiesch, M.; Grischke, J. The effect of adjuvant oral irrigation on self-administered oral care in the management of peri-implant mucositis: A randomized controlled clinical trial. Clin. Oral Implant. Res. 2020, 31, 946-958. [CrossRef] [PubMed] 
74. Tutwiler, V.; Wang, H.; Litvinov, R.I.; Weisel, J.W.; Shenoy, V.B. Interplay of Platelet Contractility and Elasticity of Fibrin/Erythrocytes in Blood Clot Retraction. Biophys. J. 2017, 112, 714-723. [CrossRef]

75. Kim, O.V.; Litvinov, R.I.; Alber, M.S.; Weisel, J.W. Quantitative structural mechanobiology of platelet-driven blood clot contraction. Nat. Commun. 2017, 8, 1274. [CrossRef] [PubMed]

76. Qiu, Y.; Brown, A.C.; Myers, D.; Sakurai, Y.; Mannino, R.G.; Tran, R.; Ahn, B.; Hardy, E.T.; Kee, M.F.; Kumar, S.; et al. Platelet mechanosensing of substrate stiffness during clot formation mediates adhesion, spreading, and activation. Proc. Natl. Acad. Sci. USA 2014, 111, 14430-14435. [CrossRef] [PubMed] 